\title{
Understory bat roosts, availability and occupation patterns in a Neotropical rainforest of Costa Rica
}

\author{
David Villalobos-Chaves ${ }^{1 *}$, Jendry Vargas Murillo ${ }^{2}$, Emmanuel Rojas Valerio ${ }^{3}$, Brian W. Keeley ${ }^{4}$ \\ \& Bernal Rodríguez-Herrera ${ }^{1}$ \\ 1. Escuela de Biología, Universidad de Costa Rica, 2060 San José, Costa Rica; david.villaloboschaves@ucr.ac.cr, \\ bernal.rodriguez@ucr.ac.cr \\ 2. Escuela de Biología, Universidad Nacional, 86-3000 Heredia, Costa Rica; yendryv@hotmail.com \\ 3. Reserva Biológica Tirimbina, 74-3069 Sarapiquí, Heredia, Costa Rica; emmanuel@tirimbina.org \\ 4. School of Forestry, Northern Arizona University, 2727 North Jamison Boulevard, Flagstaff, AZ 86004 USA; \\ abkeeley@q.com \\ * Correspondence
}

Received 02-IX-2015. C Corrected 11-III-2016. Accepted 03-IV-2016.

\begin{abstract}
The strong link between bats and their roosts is widely recognized as being particularly significant. Despite this, roosting ecology of bats is poorly understood and much of the basic information is still unknown. In this study, we investigated the availability and occupation patterns of four roost types (trees, caves, termite nests and tents) used by bats at Tirimbina Biological Reserve (TBR), Costa Rica. To accomplish our aim, we systematically surveyed both sides of established trails and transects, looking for understory roosts. Potential roosts were examined for bat presence in order to establish occupation. Roost availability and density were estimated using traveled distances $(\mathrm{km})$ and inspected area $(10 \mathrm{~m}$ for trees/caves and $15 \mathrm{~m}$ for tents/termite nests) of each trail or transect sampled. For the tent roosts, data on taxonomic information of plant modified, type of architecture, condition and construction achievement were also recorded. The area surveyed represented 45.4 $\%$ of the total area of the TBR (345 ha). Tents were the most common roost ( $56.6 \%$ of all roosts, $\mathrm{N}=223$ ), followed by trees $(24.4 \%, \mathrm{~N}=96)$, termite nests $(18.8 \%, \mathrm{~N}=74)$ and caves $(0.2 \%, \mathrm{~N}=1)$. We detected only 27 roosts occupied by bats $(6.8 \%$ of all roosts, 0.17 occupied roosts/ha). Caves showed the highest occupation rate $(100 \%, \mathrm{~N}=1)$, followed by trees $(17.7 \%, \mathrm{~N}=17)$, tents $(3.6 \%, \mathrm{~N}=8)$ and termite nests $(1.3 \%, \mathrm{~N}=1)$. We found the roosts for 10 species, representing $33.9 \%$ of the bat fauna documented at the reserve (62 species). Density of roosts per bat species varied between $0.017-0.138$ roosts/ha. Phyllostomidae was the best-represented family with Micronycteris microtis representing the most common species encountered. Four distinct tent architectures were documented. Bifid architecture was the most common (133 tents), followed by Conical (47 tents), Apical (27 tents) and Inverted Boat (16 tents). Most of the tents found were healthy $(76.7 \%, \mathrm{~N}=171)$ and totally constructed $(88.8 \%, \mathrm{~N}=198)$. Our study demonstrated that occupied bat roosts are difficult to find in the forest. When compared to the roost availability, the low occupation rates suggested that, at least in our study area, roosts might not be a limiting resource. Nevertheless, to confirm this hypothesis, information about fidelity and selection process of the species is fundamental for understanding to what extent these roosts meet the requirements to be inhabited or modified. Worldwide conservation efforts on bats should focus on understanding roosting ecology, especially due to anthropogenic pressures that are continuously reducing the availability of roosts, which undoubtedly contributes to the risk of extinction for specialized and sensitive species. Rev. Biol. Trop. 64 (3): 1333-1343. Epub 2016 September 01.
\end{abstract}

Key words: Costa Rica, Neotropical bats, Phyllostomidae, roosting ecology, bat tents, Sarapiquí.

Neotropical bat species are particularly abundant and diverse (Fenton, 1992; Kalko, 1998). With about 98 genera and 385 species (Solari \& Martínez-Arias, 2014) they represent around $30 \%$ of the global number of bat species and over $50 \%$ of mammalian species locally. As possible explanations, some authors have proposed that this incredible 
diversity in Chiroptera is explained by variables such as spatial heterogeneity (Kalko \& Handley, 2001), diet and foraging habitats (Kalko, 1998) and roost availability (Humphrey, 1975; Kalko, 1998).

It is widely recognized that roosts are considered one of the most biologically significant resources for these mammals (Kunz, 1982; Grindal \& Brigham, 1999; Fenton, 2003). Because bats spend the entire daylight hours and frequently visit roosts during nightly activities, they spend more than half of their life in roosts, therefore the availability and quality of this resource is critical (Kunz, 1982). Roosts are important sites used by bats for mating, hibernation and rearing young, besides they facilitate social interactions, offer protection from weather or predators, minimize energy expenditure (Kunz, 1982) and even can limit the presence, abundance and diversity of bats species in an area (Humphrey, 1975; Kalko, 1998; Aguirre, Lens, \& Matthysen, 2003). Roost resources are highly variable, ranging from mines, caves, rock crevices and tree hollows, foliage, modified leaves, live termite nests, armadillo holes to man-made structures (Kunz, 1982; Simmons, Voss, \& Fleck, 2002; Kunz \& Lumsden, 2003). The presence of these resources could facilitate the coexistence of multiple species within small but highly diverse regions (Humphrey, 1975; Kalko, 1998).

Despite the importance of roosts to bat ecology, information is lacking about the roosts or the roosting ecology for most bat species (Fenton et al., 2001; Agosta, 2002). In Neotropical regions where occupied day roosts can be extremely difficult to locate (Aguirre et al., 2003), basic but critical roost information like occupation, preferences, selection, density and abundance are almost nonexistent for most species (Díaz \& Linares García, 2012). Information available for some few species suggest that occupation patterns of the bats are shaped by factors like fidelity or lability of the species or individuals, predation, parasitism and roost availability and permanency (Lewis, 1995). On the other hand, selection process of roosting resources is another complex bat behavior that is influenced by several variables like structural roost characteristics, macro and micro habitat associated to it, roost availability and bat species preferences (Timm \& Mortiner, 1976; Choe \& Timm, 1985; Timm \& Lewis, 1991; Stoner, 2000; Aguirre et al., 2003; Kalko, Ueberschaer, \& Dechmann, 2006; Rodríguez-Herrera, Medellín, \& Gamba-Ríos, 2008; Solano-Quesada \& Sandoval, 2010). For example, variables like tree diameter and inner width of the cavities used by the bats (Aguirre et al., 2003) or canopy and understory coverage around roosting resources (Rodríguez-Herrera et al., 2008) have been identified as fundamental for roost selection or construction, respectively.

Considering the influence of roosts on bat ecology and evolution (Kunz, 1982) and the lack of information available for Neotropical species, gathering basic knowledge of roosting ecology is essential for designing further studies that assist the development of reliable conservation strategies. This becomes even more imperative when considering that ongoing anthropogenic factors like deforestation, fragmentation and forest management practices are tangible forces that likely reduce roosts availability and quality, which negatively influences bat populations (Kunz \& Lumsden, 2003). In this paper, we present novel information about important factors directly related to the roosting ecology of Neotropical bats. Our main purpose was to describe the availability and occupation patterns of several roosting resources used by bats in a Neotropical rainforest of Costa Rica, as well as examine these patterns from an ecological and conservation perspective.

\section{MATERIALS AND METHODS}

Study site: Fieldwork was conducted in July 2009, October and November 2011, and October 2012 on Tirimbina Biological Reserve (TBR), Sarapiquí, Heredia Province, Costa Rica (TBR; $10^{\circ} 24^{\prime} \mathrm{N}-84^{\circ} 07^{\prime} \mathrm{W}$ ). The study site is covered with tropical wet forest (Holdridge, 1967). Elevation ranges from 40 to 
$150 \mathrm{~m}$, and the average temperature and precipitation is $25.3^{\circ} \mathrm{C}$ and $3900 \mathrm{~mm}$ respectively (McDade, Bawa, Hespenheide, \& Hartshorn, 1994). TBR is approximately 345 ha, composed of primary and secondary forest and a small proportion of abandoned cacao plantation (Theobroma cacao) surrounded by a complex matrix composed of man-made structures (i.e., La Virgen de Sarapiquí town), pastures, diverse kinds of plantations (e.g., trees, banana, pineapple, others) and forest patches of differing size and diversity.

Roost sampling: We searched for the following bat roost within the study area: (1) Trees (including hollow trees and fallen trees with prominent logs; Fig. 1A and Fig. 1B), (2) Caves (Fig. 1C), (3) Termite nests (Fig. 1D)
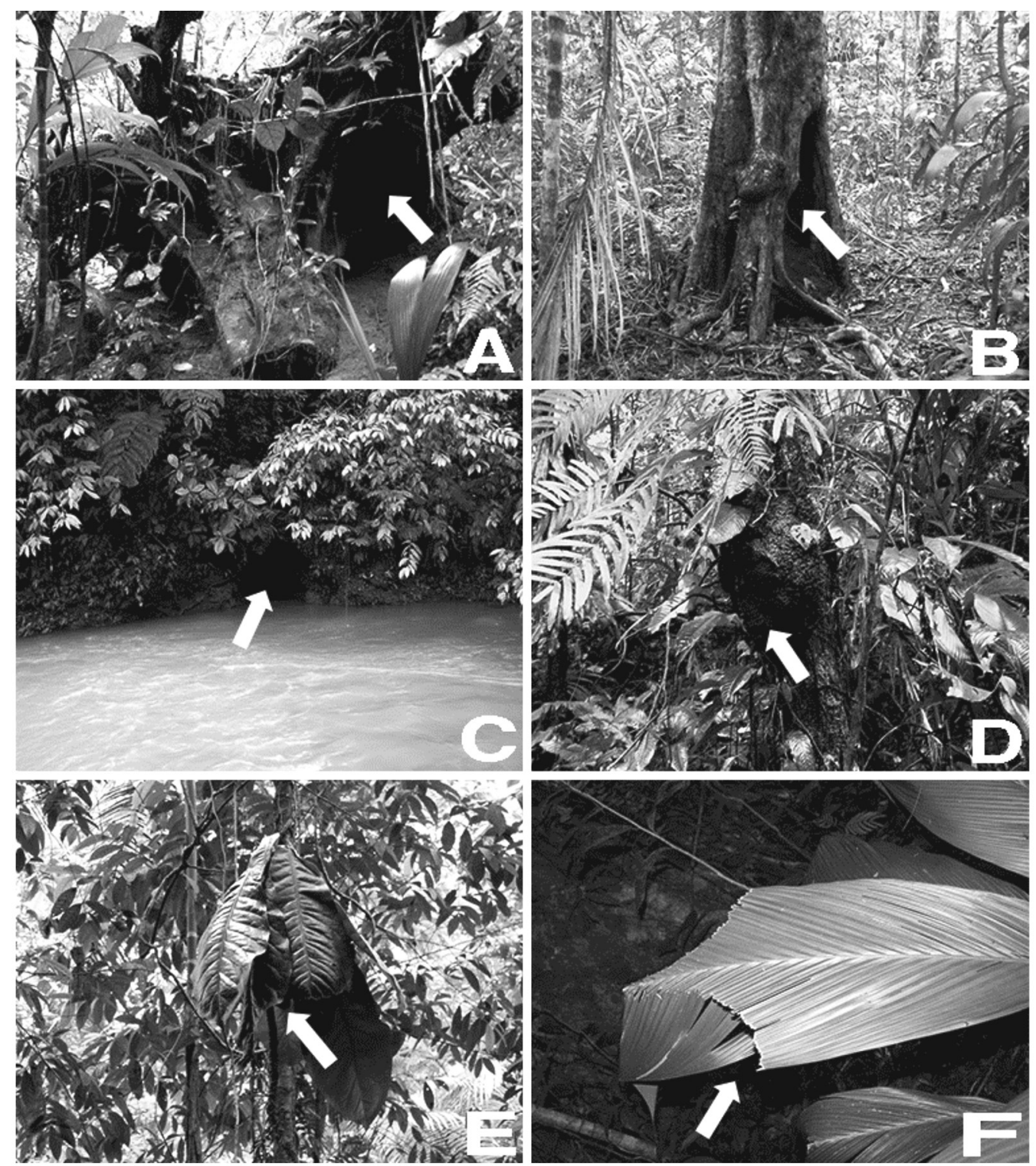

Fig. 1. Classification of roosts occupied by bats. (A-B) trees; (C) caves; (D) termite nests and (E-F) tents. Arrows indicated the entrance to the roost. 
and (4) Modified leaves or 'tents' (Fig. 1E and Fig. 1F). Leaf tents deserve special attention because unlike other roost types most of them may last for only a few weeks or months. Thus, in order to obtain information for these ephemeral roosts, we recorded for each tent the following variables: (A) the type of architecture or design (Table A; based on Kunz, Fujita, Brooke, \& McCraken, 1994; Rodríguez-Herrera, Medellín, \& Timm, 2007), (B) the family and species of plant or leaf modified (as possible), (C) the construction achievement (total or partial: plants or leaves with or without all the necessary cuts to achieve the final design, respectively) and (D) the condition (damaged or healthy: significant or non-significant deterioration or physical damage in the plant or leaf). We then examined the influence of each variable on the occupation patterns of the tent roosting bats. Other bat roosts, such as crevices and unmodified leaves were excluded from the samplings and analysis due to the difficulty to obtain accurate and reliable information about these roost types with our sampling design.

Availability and occupation of roosts: Throughout the forest reserve, we systematically surveyed established trails and non-linear transects away from the trails by calculating traveled distances $(\mathrm{km})$ with the "track function" of a global position system (GPSmap 60CSx; Garmin International Inc., Olathe, Kansas, USA). Along each trail and transect, we searched for roosts in trees and caves for approximately $10 \mathrm{~m}$ on both sides, and we allowed for $15 \mathrm{~m}$ in the case of tents and termite nests. Observations were conducted in the morning (7:00-11:00) and in the afternoon (14:00-17:00). We surveyed approximately 11 trails and 65 transects of different lengths in the study area (range: $300-2500 \mathrm{~m}$ ). The total area examined represented 156.7 ha (45.4\%) of the total 345 ha of the TBR. Each potential roost was carefully examined for bat presence (individuals) and permanently tagged in order to relocate it and avoid replication during sampling periods. We classified roosts as occupied if bats were present during the visual inspection, and unoccupied or empty if the roost was inhabited. Direct observation performed with the help of a red light, photographs and captures (using a mist net placed at the roost entrance) were used to determine the number of individuals and species using each roost (occupation). We used the track length and the search distance from both sides of each track to calculate the total sampling area (in hectares) by roost type and the availability of roost type per area. This information was also used to assess the density of roosts occupied by each bat species (roosts per hectare).

Finally, in order to complement the information collected during our study, we also include observations made outside of the study period by two of the authors (B. RodríguezHerrera \& D. Villalobos-Chaves pers. obs.). These observations include bat species that we did not encounter during the study. Although they were not included in the statistical analyses since they do not fit with the systematical survey, they help us understand how the community of bats uses the roosting resources of TBR.

Chi-square test was used to evaluate tent characteristics. Availability and occupation patterns of the roosts in the study area were also examined with chi-square tests, however for these calculations it was necessary to make a size area correction due to the differences in the size of the surveyed areas per roost type. All analyses were conducted using R statistical software (version 2.15.3; R Development Core Team, 2015).

\section{RESULTS}

In total, we surveyed 57.9 ha for trees and caves, 55 ha for tents and 44.2 ha for termite nests. Combining all roost types we found 394 roosts. Leaves modified by bats represented the most frequent roost $(56.6 \%$ of all roosts, Number of roosts, $\mathrm{N}=223)$, followed by trees $(24.4$ $\%, \mathrm{~N}=96)$, termite nests $(18.8 \%, \mathrm{~N}=74)$ and caves $(0.2 \%, N=1)$ (Fig. 2). Significant differences in the total number of available roosts $\left(X^{2}=223.20\right.$, d.f $\left.=3, \mathrm{P}<0.05\right)$ were found. 


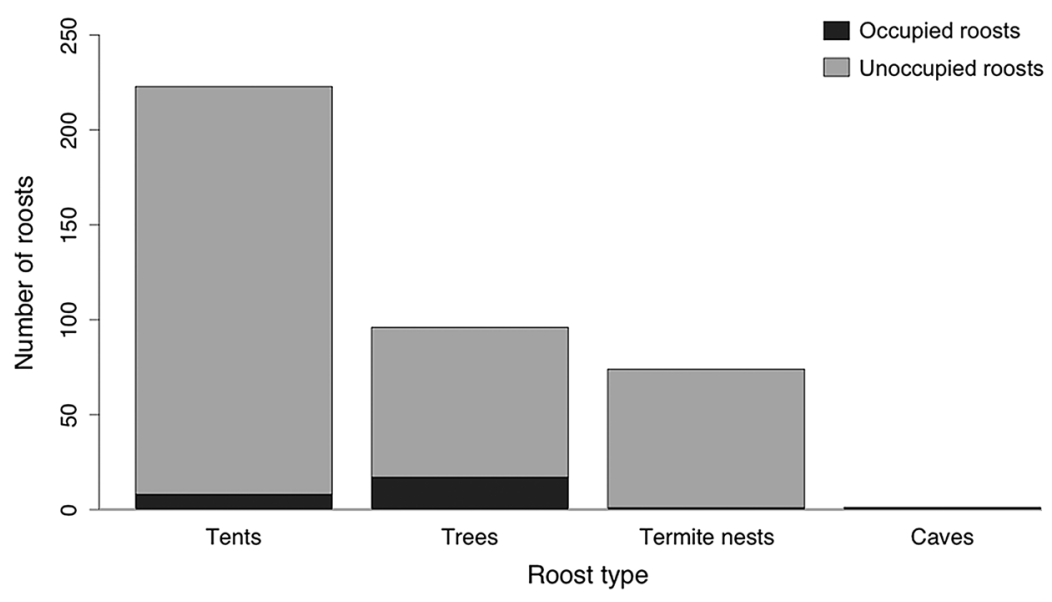

Fig. 2. Occupation patterns of bats by roost type.

Of the 394 roosts, occupied roosts were uncommon, with only 27 roosts being used by bats $(6.8 \%$ of all roosts) and 367 unoccupied roosts (93.1 \% of all roost; Fig. 2). Highest occupation rate was observed for the caves $(100 \%, \mathrm{~N}=1)$, followed by the trees $(17.7 \%$, $\mathrm{N}=17)$, tents $(3.6 \%, \mathrm{~N}=8)$ and finally the termite nests $(1.3 \%, \mathrm{~N}=1)$ (Fig. 2). Chi-squared analysis showed that unoccupied roosts were more common than expected $\left(X^{2}=606.29\right.$, d.f $=3, \mathrm{P}<0.05)$ and that occupation patterns differ significantly between roost type $\left(X^{2}=\right.$ 19.06 , d.f $=3, \mathrm{P}<0.05)$. The occupation of trees was higher than expected, meanwhile for tents, termite nests and caves observed occupation was lower than expected.

Roosts for 10 species of bats belonging to two families (Table 1) were found during our sampling periods. In Table 1, we added observations of occupied bat roosts made in the study area but outside of the study period, which increases our total number of species to 21 , representing $33.9 \%$ of the bat species documented in the study area (62 species; B. Rodríguez-Herrera unpublished data). The density of occupied roosts in the study area was 0.17 roosts/ha, meanwhile density of roosts per bat species varied between 0.017-0.138 roosts/ha (Table 1). Phyllostomidae was the best-represented family, with a total of eight species. Within all bat families, M. microtis was the most common species found in roosts. Regarding tent-roosting bats, we found that Dermanura watsoni was the most common species in tents (Table 1).

Four types of tent architectures were documented in our study area (Table 2). Bifid was the most common design (133 tents; $X^{2}=$ 151.58 , d.f $=3, \mathrm{P}<0.05$ ) and were highly associated with leaves of Arecaceae and Cyclanthaceae families that were used by bat species like D. watsoni and Mesophylla macconelli (Table 1). Leaves of Asplundia spp., Geonoma spp. and Asterogyne spp. were the primary resource used by bats to construct Bifid tents in TBR (Table 2). Conical architecture was the second most common design (47 tents). Plants such as Potalia turbinata (Gentianaceae) and Ardisia brenesii (Myrsinaceae) were those used by bats to create this kind of tent. Apical and Inverted Boat architectures (27 and 16 tents, respectively) were the least common designs. Apical tents were usually constructed from the leaves of Philodendron spp. (Araceae), Piper spp. (Piperaceae) and Pentagonia spp. (Rubiaceae), whereas Inverted Boat tents were mainly constructed using the leaves of Heliconia spp. (Heliconiaceae) and Rhodospatha spp. (Marantaceae). The condition criteria and construction achievement classification system used for the tents showed that most of the tents in the study area were in good condition 
TABLE 1

Details of roosts per bat species found at Tirimbina Biological Reserve, Sarapiquí, Costa Rica

\begin{tabular}{|c|c|c|}
\hline Family/Species & Roosts description & Density (roosts/ha) \\
\hline \multicolumn{3}{|l|}{ Emballonuridae } \\
\hline Cormura brevirostris & Fallen tree trunk and logs & 0.069 \\
\hline Centronycteris centralis* & Unmodified leaves, tree trunk & n.d \\
\hline Cyttarops alecto* & Unmodified leaves & n.d \\
\hline Saccopteryx bilineata & Hollow tree trunk & 0.069 \\
\hline Saccopteryx leptura* & Alive tree trunk & n.d \\
\hline \multicolumn{3}{|l|}{ Phyllostomidae } \\
\hline Carollia perspicillata & Cave & 0.017 \\
\hline Carollia sowelli & Cave & 0.017 \\
\hline Carollia castanea* & Crevice & n.d \\
\hline Carollia sp. & Fallen tree trunk & n.d \\
\hline Dermanura watsoni & $\begin{array}{l}\text { Tents in Asterogyne martiana, Piper spp., Geonoma congesta, } \\
\text { G. cuneata, and Dicranopygium umbrophilum }\end{array}$ & 0.072 \\
\hline Desmodus rotundus* & Cave & n.d \\
\hline Ectophylla alba & Tents in Heliconia imbricata & 0.054 \\
\hline Lichonycteris obscura & Fallen tree trunk, tree logs & 0.034 \\
\hline Lonchorhina aurita* & Cave & n.d \\
\hline Lophostoma brasiliense & Termite nests & 0.020 \\
\hline Lophostoma silviculum* & Termite nests & n.d \\
\hline Mesophylla macconelli* & Tents in Asplundia spp. & n.d \\
\hline Micronycteris microtis & Fallen tree trunk, tree logs, cave & 0.138 \\
\hline Vampyriscus nymphaea* & Tents in Potalia turbinata and Ardisia brenesii & n.d \\
\hline Vampyressa thyone & Tent in Philodendron sp. & 0.018 \\
\hline \multicolumn{3}{|l|}{ Thyropteridae } \\
\hline Thyroptera tricolor* & Leaves of Heliconia spp. & n.d \\
\hline Thyroptera discifera* & Dry leaves of Musa spp. & n.d \\
\hline
\end{tabular}

*Observations made out of the study period. n.d = No data.

TABLE 2

Description of the tent construction preferences of bats at Tirimbina Biological Reserve, Sarapiquí, Costa Rica

\begin{tabular}{|c|c|c|c|}
\hline $\begin{array}{l}\text { Number/ } \\
\text { Percentage of tents }\end{array}$ & Plant Family & Plant genera or species modified & $\begin{array}{c}\text { Architecture } \\
\text { associated }\end{array}$ \\
\hline $80 / 35.9$ & Araceae & $\begin{array}{l}\text { Geonoma congesta, G. cuneata, Asterogyne martiana, } \\
\text { Dicranopygium umbrophilum, Astrocaryum spp., Bactris spp. }\end{array}$ & Bifid \\
\hline $54 / 24.2$ & Cyclanthaceae & Asplundia spp. & Bifid \\
\hline $38 / 17.0$ & Gentianaceae & Potalia turbinata & Conical \\
\hline $20 / 9.0$ & Arecaceae & Philodendron spp. & Apical \\
\hline $16 / 7.2$ & Heliconiaceae & Heliconia imbricata & Inverted boat \\
\hline $9 / 4.0$ & Myrsinaceae & Ardisia brenessi & Conical \\
\hline 2/0.9 & Marantaceae & Rhodospatha spp. & Inverted boat \\
\hline 2/0.9 & Piperaceae & Piper spp. & Apical \\
\hline 2/0.9 & Rubiaceae & Pentagonia spp. & Apical \\
\hline
\end{tabular}


(76.7 \%, N = 171 tents) and had all the necessary cuts to achieve the final design $(88.8 \%$, $\mathrm{N}=198$ tents), whereas only a few portion were damaged $(23.3 \%, \mathrm{~N}=52$ tents) and/or partially constructed (11.2 \%, N = 25 tents). Significant differences were found in the condition criteria $\left(X^{2}=63.50\right.$, d.f $\left.=1, \mathrm{P}<0.05\right)$ and construction achievement $\left(X^{2}=134.21\right.$, d.f $=1, \mathrm{P}<0.05)$ of tents.

\section{DISCUSSION}

Locating bat roosts in a Neotropical rainforest is difficult. We found roosts for only a few species (even if we include observations made outside of the study period); a pattern also found in other similar studies in Lamanai, Belize (roosts of 13 species of 36 documentedFenton et al., 2001) and in French Guiana (roosts of 29 species of 78 documented-Simmons \& Voss, 1998). Density data also confirmed that occupied roosts at TBR are uncommon, since we recorded lower densities $(0.17$ roosts $/ \mathrm{ha})$ in comparison with other studies (0.88 roosts/haSimmons \& Voss, 1998) performed in smaller areas (25-ha plot). In our case, we did not obtain information on roosts of the following bat families: Noctilionidae, Mormoopidae, Molossidae and Furipteridae, as well as most Vespertilionidae and many Phyllostomidae. We hypothesized that most of the day roosts belonging to these species were highly cryptic and inconspicuous (e.g., located in the canopy or subcanopy), were located in an areas unexplored during our sampling or outside the study area. In fact, species like Molossus sinaloae, Cynomops mexicanus, Rhynchonycteris naso, Myotis nigricans, Eptesicus brasiliensis and Uroderma convexum, among others, have been found in human structures (i.e., houses, public schools, churches, others) out of the TBR area (B. Rodríguez-Herrera, unpublished data), and other species registered in our study site like Centurio senex, Sturnira parvidens, Platyrrhinus helleri, Artibeus jamaicensis and Diclidurus albus have been found roosting in canopy foliage (Goodwin \& Greenhall, 1961; Rick,
1968; Jones, Smith, \& Turner, 1971; McCarthy, 1987; Fenton et al., 2000; Fenton et al., 2001).

In comparison to the number of occupied roosts, the availability of most roost types in the study area was high (except in the case of caves which were rare). If we extrapolate these numbers to the entire 345 ha TBR forested area of the entire reserve we calculated there could be an estimated of 2558 roosts at ground level in the reserve. The low occupancy rates suggested that roosts might not be a limiting resource for bats in the study area, nevertheless, since some studies have demonstrated that occupied roosts often have specific characteristics in order to be selected by bats (Sedgeley \& O'Donnell, 1999; Aguirre et al., 2003; Jung, Thompson, \& Titman, 2004; Psyllakis \& Brigham, 2006; Kalko et al., 2006; among others), detailed information about the bat species preferences, the structural characteristics of the occupied roosts and the micro and macro habitat characteristics associated to the roosts is fundamental to understanding to what extent these roost resources meet the requirements to be inhabited (i.e., trees and caves) or to be modified (i.e., plant/leaves and termite nests). Roost fidelity is another factor that possibly influences occupation patterns observed in our study, however, since fidelity of bats is shaped by several and complex variables (i.e., resource availability and permanency, predation, parasitism, among others-Lewis, 1995), firm conclusions can only be obtained with long term studies of bat roosts. Despite this, field observation suggests that some species at the study site such as Lichonycteris obscura present low fidelity, switching roosts frequently in response of temporarily suitable foraging locations that offer high nectar availability (Tschapka, 2004), and others as Carollia perspicillata and C. sowelli are highly faithful (i.e., at least for 10 years) to high quality roosts as caves.

Tent construction patterns (plant species and architectures) documented in this study area are similar to those recorded in other studies performed in the Sarapiquí basin (Melo, Rodríguez-Herrera, Chazdon, Medellín, \& Ceballos, 2009; Rodríguez-Herrera et al., 
2007), however, it could change according to locality (Rodríguez-Herrera et al. 2007). For example, bifid tents constructed in plant species of Geonoma spp., Asplundia spp., and Asterogyne spp. were highly common in TBR area; these tents are mostly constructed and used by D. watsoni and are associated with understory palms and Cyclanthaceae (Rodríguez-Herrera et al., 2007), nevertheless, authors like Choe and Timm (1985) and Chaverri and Kunz (2006) described that tent use by the same bat species (D. watsoni) in Southwestern Costa Rica differs in the composition of plant species modified and in the tent design constructed. Plant and design preferences also could change in time, since in the same locality $D$. watsoni inhabited mainly apical tents on Anthurium ravenii (Araceae-Choe \& Timm, 1985), and some years later, tent use of the same bat species were more related to umbrella and bifid designs in Carludovica palmata and in Asplundia alata, respectively (Chaverri \& Kunz, 2006). Our results support the idea that tent design composition and plants used by bats to construct their roosts could change in response to several non-independent variables such as plant resource availability through space, time and bat species preferences and behavioral plasticity (Choe \& Timm, 1985; Chaverri \& Kunz, 2006; Rodríguez-Herrera et al., 2007).

There are many variables that could influence the probability of detecting an occupied tent. These variables include since the sheer number of leaf roosts found in a given area, the diversity of available plant species to construct tents in the lowland rainforest of Sarapiquí (Rodríguez-Herrera et al., 2007), the ability of some species to modify several plants (Rodríguez-Herrera et al., 2007), the accumulation of tents over time, the unpredictable time expended in construction (bats can construct a tent in a few hours but may take weeks; Rodríguez-Herrera et al., 2007) to the construction of several tents for different purposes (e.g., escape of predators-Brooke, 1990; Timm \& Clauson, 1990; Kunz \& McCracken, 1996; controlling parasitism-Timm, 1987; and to access multiple feeding areas-Charles-Dominique,
1993). Since most of the tents were deemed functional (healthy and totally achieved), we do not believe any of these factors influenced occupancy rates, which could imply that the bats are constructing tents for reasons other than to be used merely as day roosts. High density of occupied tents was detected for $D$. watsoni, result probably related to the flexibility of this species to use at least 41 plant species modified into several architectures (RodríguezHerrera et al., 2007) and for belonging (D. watsoni was formerly know as Artibeus watsoni; Rodríguez-Herrera, Ramírez-Fernández, Villalobos-Chaves, \& Sánchez, 2014) to one of the most abundant frugivorous bat genera in the Neotropics (Bonaccorso, 1979; Medellín, Equiua, \& Amin, 2000).

Roosts are a fundamental part of the life history of bats (Kunz, 1982), so the presence of this resource is essential to reproduction and survival of populations (Kunz, 1982; Kerth, 2008; Sagot \& Chaverri, 2015). Conservation efforts for bats must include protection of roost resources (Kunz \& Lumsden, 2003), especially if we take into account that human activities are increasingly turning large forested areas into mixed landscapes, fragmented areas and manmade structures (Daily, Ceballos, Pacheco, Suzán, \& Sánchez-Azofeifa, 2003; Laurance, 2004; Tabarelli, Pinto, Silva, Hirota, \& Bede, 2005 ) that reduce and change the availability of important roost resources (Kunz \& Lumsden, 2003). Additionally, more specialized species are restricted to the use of a narrow set of available roosting resources, which may increase their risk of extinction (Sagot \& Chaverri, 2015). For example, considering the specialized roosting requirements of some bat species recorded in the area (Timm \& Mortiner, 1976; Kalko et al., 2006; Rodríguez-Herrera et al., 2008; Solano-Quesada \& Sandoval, 2010), the low roost density of species like Ectophylla alba and Lophostoma brasiliense, in addition to the rarity of species like Thyroptera tricolor, T. discifera, Vampyriscus nymphaea and Lophostoma silvicolum, these species could be considered as highly vulnerable to a decrease in available roosting resources in our study area. 
Finally, even in small forest fragments such as TBR, preserving natural shelters like fallen and hollow tree trunks, termite nests, tents and caves is a forward step to conservation of bat populations and the ecological services they provide (Sagot \& Chaverri, 2015).

\section{ACKNOWLEDGMENTS}

We thank the staff of Tirimbina Biological Reserve for their help and support during the study. Our most sincere gratitude to Eugenia Cordero Schmidt, Eduardo Chacón, Luis Sandoval, María Runnebaum and the anonymous reviewers for their assistance and comments that improved the manuscript in several ways. Finally, we are gratefully with all students that help to conclude this work.

\section{RESUMEN}

Refugios de murciélagos en el sotobosque, disponibilidad y patrones de ocupación en un bosque Neotropical lluvioso de Costa Rica. La estrecha relación entre los murciélagos y sus refugios es ampliamente reconocida por ser de particular importancia. A pesar de esto, la ecología de los refugios en murciélagos es pobremente comprendida y gran parte de la información básica aún es desconocida. En este estudio, investigamos la disponibilidad y los patrones de ocupación de cuatro tipos de refugios (árboles, cuevas, termiteros y tiendas) utilizados por los murciélagos en la Reserva Biológica Tirimbina (RBT), Costa Rica. Para lograr nuestro objetivo, nosotros inspeccionamos sistemáticamente ambos lados de senderos establecidos y transectos, en busca de refugios a nivel del sotobosque. Los refugios potenciales fueron examinados en busca de murciélagos con el fin de establecer la ocupación de los mismos. La disponibilidad y densidad de los refugios fue estimada utilizando la distancia recorrida $(\mathrm{km})$ y el área inspeccionada (10 m para árboles/cuevas y $15 \mathrm{~m}$ para tiendas/termiteros) de cada sendero o transecto muestreado. Para los refugios en tiendas, también se registraron datos sobre información taxonómica de la planta modificada, el tipo de arquitectura, la condición y la consecución de la construcción. El área inspeccionada representa el $45.4 \%$ del área total de la RBT (345 ha). Las tiendas fueron el refugio más común ( $56.6 \%$ de todos los refugios, $\mathrm{N}=223$ ), seguido por los árboles $(24.4 \%, \mathrm{~N}=96)$, los termiteros $(18.8 \%, \mathrm{~N}=74)$ y las cuevas $(0.2 \%, \mathrm{~N}=1)$. Detectamos únicamente 27 refugios ocupados por murciélagos $(6.8 \%$ de todos los refugios, 0.17 refugios ocupados/ha). Las cuevas mostraron la tasa más alta de ocupación ( $100 \%, \mathrm{~N}=1)$, seguido por los árboles $(17.7 \%, \mathrm{~N}=17)$, las tiendas $(3.6 \%, \mathrm{~N}=8)$ y los termiteros $(1.3 \%, \mathrm{~N}=1)$. Encontramos los refugios de 10 especies, lo que representa un $33.9 \%$ de la fauna de murciélagos documentada en la reserva (62 especies). La densidad de refugios por especie de murciélago varió entre 0.017-0.138 refugios/ha. Phyllostomidae fue la familia mejor representada, con Micronycteris microtis como la especie más común encontrada en los refugios. Cuatro tipos de arquitectura fueron documentadas en las tiendas. La arquitectura Bífida fue la más común (133 tiendas), seguida por la Cónica (47 tiendas), la Apical (27 tiendas) y la Bote Invertido (16 tiendas). La mayoría de las tiendas encontradas se encontraban en buen estado $(76.7 \%, \mathrm{~N}=$ 171) y totalmente construidas $(88.8 \%, \mathrm{~N}=198)$. Nuestro estudio demostró que encontrar refugios ocupados por murciélagos en el bosque es difícil. Cuando es comparada con la disponibilidad de refugios, la baja tasa de ocupación sugiere que, al menos en nuestra área de estudio, los refugios podrían no ser un recurso limitante. No obstante, para confirmar esta hipótesis, información acerca de la fidelidad y el proceso de selección de las especies es fundamental para comprender en que medida estos refugios cumplen con los requerimientos para ser habitados o modificados. A nivel mundial, los esfuerzos de conservación de los murciélagos deberían priorizar en comprender la ecología de los refugios, especialmente debido a que las presiones antropogénicas están continuamente reduciendo la disponibilidad de este recurso, lo cual sin duda alguna contribuye al riesgo de extinción para las especies más sensibles y especializadas.

Palabras clave: Costa Rica, murciélagos neotropicales, Phyllostomidae, ecología de los refugios, tiendas de murciélagos, Sarapiquí.

\section{REFERENCES}

Aguirre, L. F., Lens, L., \& Matthysen, E. (2003). Patterns of roost use by bats in a neotropical savanna: Implications for conservation. Biological Conservation, 111(3), 435-443.

Agosta, S. J. (2002). Habitat use, diet and roost selection by the big brown bat (Eptesicus fuscus) in North America: A case for conserving an abundant species. Mammal Review, 32(3), 179-198.

Bonaccorso, F. J. (1979). Foraging and reproductive ecology in a Panamanian bat community. Bulletin of the Florida State Museum: Biological Sciences, 24, 359-408.

Brooke, A. P. (1990). Tent selection, roosting ecology and social organization of the tent-making bat, Ectophylla alba, in Costa Rica. Journal of Zoology (London), 221(1), 11-19.

Charles-Dominique, P. (1993). Tent-Use by the Bat Rhinophylla pumilio (Phyllostomidae: Carolliinae) in French Guiana. Biotropica, 25(1), 111-116. 
Chaverri, G., \& Kunz, T. H. (2006). Roosting ecology of the tent-roosting bat Artibeus watsoni (Chiroptera: Phyllostomidae) in southwestern Costa Rica. Biotropica, 38(1), 77-84.

Choe, J. C., \& Timm, R. M. (1985). Roosting site selection by Artibeus watsoni (Chiroptera: Phyllostomidae) on Anthurium ravenii (Araceae) in Costa Rica. Journal of Tropical Ecology, 1, 241-247.

Daily, G. C., Ceballos, G., Pacheco, J., Suzán, G., \& Sánchez-Azofeifa, A. (2003). Countryside biogeography of neotropical mammals: Conservation opportunities in agricultural landscapes of Costa Rica. Conservation Biology, 17(6), 1814-1826.

Díaz, M. M. \& Linares García, V. H. (2012). Refugios naturales y artificiales de Murciélagos (Mammalia: Chiroptera) en la selva baja en el Noroeste de Perú. Gayana, 76(2), 117-130.

Fenton, M. B. (1992). Bats. New York: Facts on File, Inc.

Fenton, M. B. (2003). Science and the conservation of bats: Where to next? Wildlife Society Bulletin, 31(1), 6-15.

Fenton, M. B., Bernard, E., Bouchard, S., Hollis, L., Johnston, D. S., Lausen, C. L., Ratcliffe, J. M., Riskin, D. K., Taylor, J. R., \& Zigouris, J. (2001). The bat fauna of Lamanai, Belize: roosts and trophic roles. Journal of Tropical Ecology, 17(4), 511-524.

Fenton, B. M., Vonhof, M. J., Bouchard, S., Gill, S. A., Johnston, D. S., Reid, F. A., Riskin, D. K., Standing, K. L., Taylor, J. R., \& Wagner, R. (2000). Roosts Used by Sturnira lilium (Chiroptera: Phyllostomidae). Biotropica, 32(4a), 729-733.

Goodwin, C. G., \& Greenhall, A. M. (1961). A review of the bats of Trinidad and Tobago, descriptions, rabies infection, and ecology. Bulletin of the American Museum of Natural History, 122(3), 187-302.

Grindal, S. D., \& Brigham, R. M. (1999). Impacts of forest harvesting on habitat use by foraging insectivorous bats at different spatial scales. Ecoscience, $6(1), 25-34$.

Holdridge, L. R. (1967). Life zone ecology. San José: Tropical Science Center.

Humphrey, S. R. (1975). Nursery roosts and community diversity of Nearctic bats. Journal of Mammalogy, 56(2), 321-346.

Jones, J. K., Smith, J. D., \& Turner, R. W. (1971). Noteworthy records of bats from Nicaragua, with a checklist of the chiropteran fauna of the country. Occasional Papers of the Museum of Natural History, the University of Kansas, 17, 1-35.

Jung, T. S., Thompson, I. D., \& Titman, R. D. (2004). Roost site selection by forest-dwelling male Myotis in central Ontario, Canada. Forest Ecology and Management, 202, 325-335.

Kalko, E. K. V. (1998). Organisation and diversity of tropical bat communities through space and time. Zoology, 101, 281-297.

Kalko, E. K. V., \& Handley, C. O. Jr. (2001). Neotropical bats in the canopy: diversity, community structure, and implications for conservation. Plant Ecology, 153(1-2), 319-333.

Kalko, E. K. V., Ueberschaer, K., \& Dechmann, D. (2006). Roost Structure, Modification, and Availability in the White-throated Round-eared Bat, Lophostoma silvicolum (Phyllostomidae) Living in Active Termite Nests. Biotropica, 38(3), 398-404.

Kerth, G. (2008). Causes and consequences of sociality in bats. BioScience, 58(8), 737-746.

Kunz, T. H. (1982). Roosting ecology of bats. In T. H. Kunz (Ed.), Ecology of bats (pp. 1-56). New York: Plenum Press.

Kunz, T. H., Fujita, M. S., Brooke, A. P., \& McCraken, G. F. (1994). Convergence in tent architecture and tent-making behavior among Neotropical and Paleotropical bats. Journal of Mammalian Evolution, 2(1), 57-78.

Kunz, T. H., \& Lumsden, L. F. (2003). Ecology of cavity and foliage roosting bats. In T. H. Kunz, \& M. B. Fenton (Eds.), Bat ecology (pp. 3-89). Chicago: The University of Chicago Press.

Kunz, T. H., \& McCraken, G. F. (1996). Tents and harems: apparent defence of foliage roosts by tent-making bats. Journal of Tropical Ecology, 12(1), 121-137.

Laurance, W. F. (2004). Forest-climate interactions in fragmented tropical landscapes. Philosophical Transactions of the Royal Society of London B: Biological Sciences, 359(1443), 345-352.

Lewis, S. E. (1995). Roost Fidelity of Bats: A Review. Journal of Mammalogy, 76(2), 481-496.

McCarthy, T. J. (1987). Distributional records of bats from the Caribbean lowlands of Belize and adjacent Guatemala and Mexico. Fieldiana Zoology, 39, 137-162.

McDade, L. A., Bawa, S. L., Hespenheide, H. A., \& Hartshorn, G. S. (1994). La Selva, ecology and natural history of a Neotropical rain forest. Chicago: The University of Chicago Press.

Medellín, R. A., Equiua, M., \& Amin, M. A. (2000). Bat diversity and abundance as indicators of disturbance in Neotropical Rainforests. Conservation Biology, 14(6), 1666-1675.

Melo, F. P. L., Rodríguez-Herrera, B., Chazdon, R. L., Medellín, R. A., \& Ceballos, G. G. (2009). Small 
Tent-Roosting Bats Promote Dispersal of LargeSeeded Plants in a Neotropical Forest. Biotropica, 41(6), 737-743.

Psyllakis, J. M., \& Brigham, R. M. (2006). Characteristics of diurnal roosts used by female Myotis bats in subboreal forests. Forest Ecology and Management, 223(1-3), 93-102.

R Core Team. (2013). R: A language and environment for statistical computing. R Foundation for Statistical Computing, Vienna, Austria. ISBN 3-900051-07-0, URL http://www.R-project.org/.

Rick, A. M. (1968). Notes on bat from Tikal, Guatemala. Journal of Mammalogy, 49(3), 516-520.

Rodríguez-Herrera, B., Medellín, R. A., \& Timm, R. M. (2007). Murciélagos Neotropicales que acampan en hojas: Neotropical tent-roosting bats. Heredia: Editorial Instituto Nacional de Biodiversidad.

Rodríguez-Herrera B., Medellín, R. A., \& Gamba-Ríos, M. (2008). Roosting requirements of white tent-making bat Ectophylla alba (Chiroptera: Phyllostomidae). Acta Chiropterologica, 10(1), 89-95.

Rodríguez-Herrera, B., Ramírez-Fernández, J. D., Villalobos-Chaves, D., \& Sánchez, R. (2014). Actualización de la lista de especies de mamíferos vivientes de Costa Rica. Mastozoología Neotropical, 21(2), 275-289.

Sagot, M., \& Chaverri, G. (2015). Effects of roost specialization on extinction risk in bats. Conservation Biology, 00(0), 1-8.

Sedgeley, J. A., \& O’Donnell, C. F. J. (1999). Roost selection by the long-tailed bat, Chalinolobus tuberculatus, in temperate New Zealand rainforest and its implications for the conservation of bats in managed forests. Biological Conservation, 88(2), 261-276.

Simmons, N. B., \& Voss, R. S. (1998). The mammals of French Guiana: a neotropical lowland rainforest fauna Part 1. Bats. Bulletin of the American Museum of Natural History, 237, 1-219.

Simmons, N. B., Voss, R. S., \& Fleck, D. W. (2002). A new Amazonian species of Micronycteris (Chiroptera:
Phyllostomidae) with notes on the roosting behaviour of sympatric congeners. American Museum Novitates, 3358, 1-16.

Solano-Quesada, M. G., \& Sandoval, L. (2010). Requirements of the roost used by Spix's disk-winged Bat (Thyroptera tricolor). Chiroptera Neotropical, 16(2), 786-788.

Solari, S. \& Matínez-Arias, V. (2014). Cambios recientes en la sistemática y taxonomía de murciélagos Neotropicales (Mammalia: Chiroptera). Therya, 5(1), 167-196.

Stoner, K. E. (2000). Leaf selection by the tent-making bat Artibeus watsoni in Asterogyne martiana palms in southwestern Costa Rica. Journal of Tropical Ecology, 16(1), 151-157.

Tabarelli, M., Pinto, L. P., Silva, J. M. C., Hirota, M., \& Bede, L. (2005). Challenges and Opportunities for Biodiversity Conservation in the Brazilian Atlantic Forest. Conservation Biology, 19(3), 695-700.

Tschapka, M. (2004). Energy density patterns of nectar resources permit coexistence within a guild of Neotropical flower-visiting bats. Journal of Zoology (London), 263(1), 7-21.

Timm, R. M. (1987). Tent construction by bats of the genera Artibeus and Uroderma. In B. D. Patterson \& R. M. Timm (Eds.), Studies in Neotropical Mammalogy: Essays in Honor of Philip Hershkovitz (pp. 187-212). Chicago: Field Museum of Natural History.

Timm, R. M., \& Clauson, B. L. (1990). A roof over their feet: Tent-making bats of the New World tropics turn leaves into living quarters. Natural History, 3/90, 54-59.

Timm, R. M., \& Lewis, S. E. (1991). Tent construction and use by Uroderma bilobatum in coconut palms (Cocos nucifera) in Costa Rica. Bulletin of the American Museum of Natural History, 206, 251-260.

Timm, R. M., \& Mortiner, J. (1976). Selection of Roost sites by Honduran White Bats, Ectophylla alba (Chiroptera: Phyllostomidae). Ecology, 57(2), 385-389.

\section{See Digital Appendix}


